\title{
The rise of a large carnivore population in Central Europe: genetic evaluation of lynx reintroduction in the Harz Mountains
}

\author{
Sarah Ashley Mueller ${ }^{1,3} \cdot$ Tobias Erik Reiners $^{1,3} \cdot$ Tomma Lilli Middelhoff $^{2} \cdot$ Ole Anders $^{2} \cdot$ Anna Kasperkiewicz $^{1}$. \\ Carsten Nowak ${ }^{1}$
}

Received: 13 August 2019 / Accepted: 24 March 2020 / Published online: 7 April 2020

(c) The Author(s) 2020

\begin{abstract}
Large carnivores have made a successful comeback across human-dominated landscapes in Central Europe. The Eurasian lynx, for instance, has been actively reintroduced in different regions. Genetic diversity is quickly eroding in these isolated, small populations, questioning the long-term success of lynx reintroductions. To track population development and genetic diversity in a reintroduced lynx population, we used microsatellite analysis and mtDNA haplotyping based on 379 samples collected during the initial 15 year period of lynx reintroduction in the Harz mountains National Park, Germany. The Harz lynx population shows higher genetic diversity relative to other lynx reintroductions, due to initial cross-breeding of divergent captive source lineages and a comparably high founder size. While the population shows significant population growth and spread into adjacent regions, genetic diversity is continiously declining. Expected heterozygosity values dropped from 0.63 after reintroduction (2006/2007) to 0.55 within a 10 year period. Despite this, the Harz lynx population is currently a viable component to an envisioned lynx metapopulation spanning across Central Europe. The ongoing genetic erosion in the Harz population along with a lack of geneflow from adjacent populations indicates that such connectivity is urgently needed to ensure long-term population persistence.
\end{abstract}

Keywords Reintroduction $\cdot$ Lynx lynx $\cdot$ Genetic diversity $\cdot$ Large carnivore $\cdot$ Inbreeding

Sarah Ashley Mueller and Tobias Erik Reiners contributed equally to the work.

Electronic supplementary material The online version of this article (https://doi.org/10.1007/s10592-020-01270-w) contains supplementary material, which is available to authorized users.

Sarah Ashley Mueller

sarah.mueller@senckenberg.de

1 Conservation Genetics Group, Senckenberg Research Institute and Natural History Museum Frankfurt, Clamecystrasse 12, 63571 Gelnhausen, Germany

2 Luchsprojekt Harz, Nationalparkverwaltung Harz, Außenstelle Oderhaus, Oderhaus 1, 37444 Sankt Andreasberg, Germany

3 Institute for Ecology, Evolution and Diversity, Goethe- University Frankfurt, Max-von-Laue-Straße 13, 60438 Frankfurt am Main, Germany

\section{Introduction}

Large carnivores, such as wolves and lynx, are currently expanding their ranges across Central and Western Europe (Chapron et al. 2014). This process of de-extinction is generally considered beneficial to restore biodiversity as native top-level predators have overall-positive effects on ecosystem function and health (Ripple et al. 2014; Schmitz et al. 2010). In contrast to wolves, Eurasian lynx (Lynx lynx) have been actively reintroduced in Central Europe in the frame of several reintroduction projects. Between 1971 and 2018, 16 reintroductions of lynx have been attempted across Central Europe (Linnell et al. 2009). These reintroductions were widely unsuccessful; establishment occurred in only five areas, while the long-term fate remains unknown for multiple reintroductions due to lack of sufficient information post release (Linnell et al. 2009).

The low success rates in lynx reintroductions stems from extremely small founder sizes, which leads to inbreeding and low genetic diversity. In fact, all genetically investigated reintroduced populations show inbreeding 
and loss of genetic diversity (Breitenmoser-Würsten and Obexer-Ruff 2003; Bull et al. 2016). Additionally, most reintroduction attempts used individuals from one source population. Another major driver of this low success rate is reintroduced populations remain isolated from other Eurasian lynx populations (Kramer-Schadt et al. 2004, 2005). This isolation is a major threat to the long-term viability of reintroduced lynx populations (MolinariJobin et al. 2010). While there is considerable data on the genetic structure of autochtonous lynx populations in Europe including phylogeographic assessments (Gugolz et al. 2008; Ratkiewicz et al. 2012; Sindičić et al. 2013a; Rodríguez-Varela et al. 2016), Europe-wide population characterization (Rueness et al. 2014; Ratkiewicz et al. 2014; Schmidt et al. 2011), fine-scale population structure (Sindičić et al. 2013a; Bagrade et al. 2016; Schmidt et al. 2016; Holmala et al. 2018) and non-invasive genetic monitoring (Davoli et al. 2013; Krojerová-Prokešová et al. 2018; Hollerbach et al. 2018), such genetic assessment of reintroduced lynx populations is sparse (Bull et al. 2016).

One reason for the absence of scientific data regarding reintroduction projects is obtaining samples for standardized genetic population monitoring is notoriously difficult for this species (Schmidt and Kowalczyk 2006; de Barba et al. 2010; La Haye et al. 2017). Hair sampling was successfully carried out by Schmidt et al. (2016) however, this approach did not prove successful in regions with less information on individual movements and marking sites. This is somewhat unfortunate, as genetic factors play an important role in the long term-viability and reintroduction success in small isolated populations. Thus, measuring and evaluating genetic diversity over time is vital to develop optimized strategies for long-term population management (Boitani et al. 2015).

Here we present a multiple-year genetic assessment of a reintroduced lynx population in the Harz Mountains (HM) in Central Germany. Official reintroduction of the Eurasian lynx in the HM started in 2000. The long term success of this reintroduction was initially regarded with skepticism (von Arx et al. 2009; Kramer-Schadt et al. 2005). In contrast to former reintroductions, where mostly wild caught lynx from Carpathian origin were used, lynx released in the HM originated from zoos and wildlife parks.

In this study we aim to describe the (i) population spread, (ii) genetic structure and diversity through time, (iii) pedigree of the wild population since reintroduction and (iv) effect of founder size on genetic diversity. We discuss these issues in respect of the captive origin of this population in contrast to other reintroduced lynx populations with founders of wild-caught origin. Understanding the success of lynx reintroductions originating from captivity has important implications for the design of future reintroductions, ultimately with the goal of creating a viable connected lynx metapopulation throughout Europe.

\section{Study area}

The study region consists of the Harz lynx population (HLP) range comprising parts of four federal states; Lower Saxony (NI), Saxony-Anhalt (ST), Thuringia (TH) and Hesse (HE). Additionally single dispersing individuals have been sampled in North Rhine-Westphalia (NW) and Bavaria (BY) (Fig. 1). The core of the current distribution is the HM where the reintroductions occurred. The HM is a low-mountain region in central Germany ranging up to $1141 \mathrm{~m}$. Approximately ten percent of the $2200 \mathrm{~km}^{2}$ area is protected under the status of a National Park (IUCN, category II). Lynx were absent in the region for more than 200 years until reintroduction occurred (Anders pers. com). Between 2000 and 2006, 24 lynx originating from German and Swedish zoos and wildlife parks were released within the National Park (9 males, 15 females) (Table S1 and Fig. 2). Additionally, at least ten lynx escaped from wildlife parks or were illegally released. Four of those animals were recaptured due to their habituation to humans. The first evidence of reproduction in the wild was reported in 2002 (Anders and Sacher 2005).

\section{Methods}

\section{Monitoring activities}

The HLP is monitored through the collection of proven and unproven lynx indications and camera traps. The intensity of monitoring has increased over time due to the greater availability of resources for such activities (Anders 2013; Anders and Sacher 2005; Anders and Middelhoff 2016a, b). Staff of the Harz National Park were responsible for the monitoring in NI and ST. Governmental agencies monitor the lynx in TH, HE, NW, and BY. Lynx reproduction occurred in HE between 2010 and 2015; NW and BY show evidence of single individuals of Harz origin (Anders pers. com). All lynx observations are classified using the Status and Conservation of the Alpine Lynx Population (SCALP) framework (Molinari-Jobin 2003) as adopted by the German monitoring authorities in 2009 (Kaczensky et al. 2009; Reinhardt et al. 2015). We considered three SCALP classes of records: $\mathrm{C} 1$ records (confirmed data e.g. georeferenced pictures, dead lynx and genetic detections) to assess lynx distribution over time. $\mathrm{C} 2$ (confirmed data, e.g. prey remains confirmed by experts) and $\mathrm{C} 3$ (unconfirmed data, e.g. sightings) were recorded but not considered in the dataset as the rate of false positives can lead to biased conclusions (Molinari-Jobin et al. 2012). 

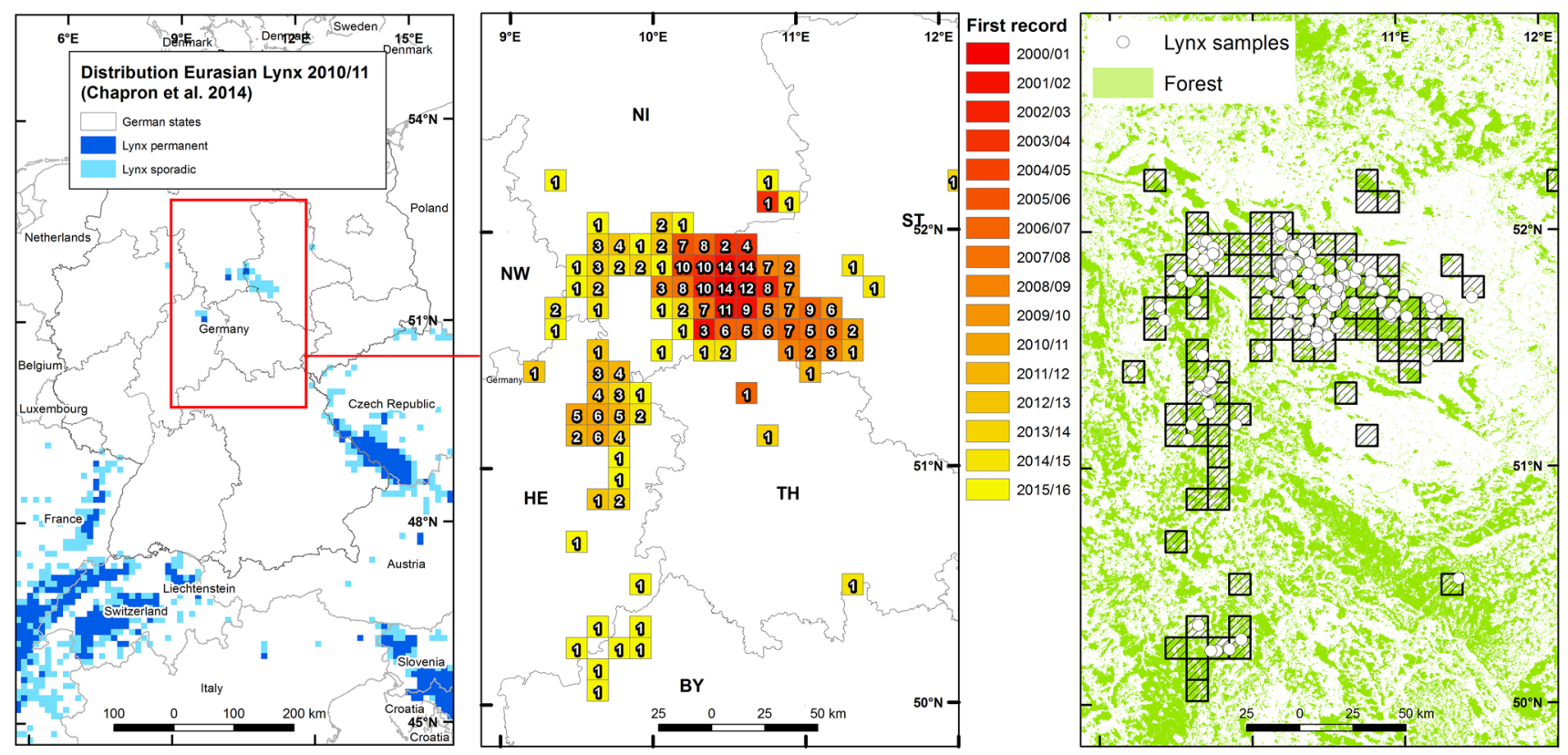

Fig. 1 a Lynx distribution according to Chapron et al. (2014) with additional data from the HLP added according to the monitoring year 2010/2011. Dark blue indicates permanent occurrence and light blue indicates sporadic occurrence. $\mathbf{b}$ The occurance of $\mathrm{C} 1$ evidence of

Telemetry was implemented in the HM in 2008. Seventeen lynx were equipped with collars until 2016. Systematic camera trapping was tested in 2012 and routinely implemented in 2014 (Anders and Middelhoff 2016a, b, Port unpubl.). To estimate lynx spatial spread, we used 10 $\mathrm{km} \times 10 \mathrm{~km}$ grid cells (EEA reference Grid) and overlaid all cells with $\mathrm{C} 1$ evidence from 2000 to 2016. Evidence of known migratory individuals was excluded from the map.

\section{Genetic sample collection}

Between 2001 and 2016, 379 genetic samples were opportunistically collected alongside standard monitoring in the study area (Table S2). In total, 41 tissue, 66 blood, 118 hair, 45 scat, and 109 saliva samples were collected. Tissue and scat samples were transferred to $96 \%$ ethanol. Hair samples were stored wrapped in filter papers with silica gel. Saliva traces were sampled with cotton swabs from carcasses and stored dry at room temperature (Harms et al. 2015).

\section{DNA extraction}

DNA from blood and tissue was isolated using the QIAGEN Blood and Tissue Kit following the manufacturer's protocols. Tissue extracts were diluted to $10 \mathrm{ng} / \mu \mathrm{l}$. Isolation of DNA from hair, saliva, and scat was carried out in a separate laboratory for noninvasive samples using the QIAGEN Investigator Kit and the QIAamp DNA Stool Kit, lynx within the study area between 2000 and 2016. The color represents the year of first appearance. The number indicates the number of years the species was detected. c Map of the 295 genetically confirmed lynx samples

respectively. Hair and saliva were eluted twice with $40 \mu \mathrm{l}$ each; elution volume of scat samples was $120 \mu \mathrm{l}$.

\section{Mitochondrial DNA analysis}

Two sequence fragments targeting the control region of mitochondrial DNA were used for species identification and haplotyping. Primers L16782 and H16922 (Gugolz et al. 2008) or primers Lynxfwd4 and Lynxrev5 (Buhrmester 2014) amplified a $180 \mathrm{bp}$ fragment or a $248 \mathrm{bp}$ fragment, respectively. The latter primer is lynx specific and designed for samples of low DNA concentration. Amplification was carried out by real-time PCR with a reaction volume of $10 \mu \mathrm{l}$. GENEIOUS 8.1 (Biomatters Limited) was used for sequence alignment and sequences were assigned to haplotypes described by Hellborg et al. 2002) and Gugolz et al. 2008)

\section{Microsatellite genotyping}

A microsatellite marker set of 19 loci and 2 sex markers were used (Table S3). The markers were derived from sets originally developed for domestic cat, Felis catus (Menotti-Raymond et al. 1999, 2005), Canadian lynx, Lynx canadensis (Carmichael et al. 2000) and Sumatran tiger, Panthera tigris sumatrae (Williamson et al. 2002). Each sample was run with a minimum of three replicates in $5 \mu \mathrm{l}$ or $10 \mu \mathrm{l}$ reaction volume using the Multiplex PCR 

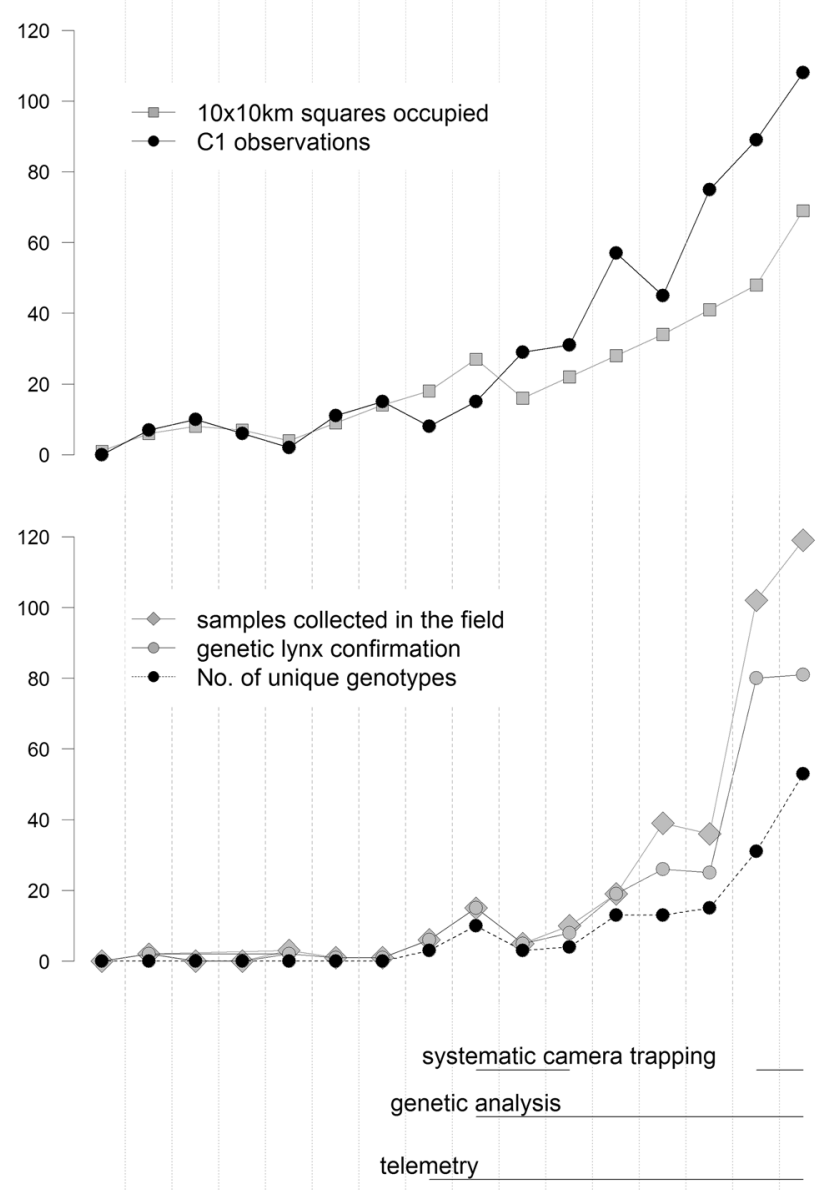

opportunistic use of camera traps

lynx monitoring activities

3) 3032 (2) rease

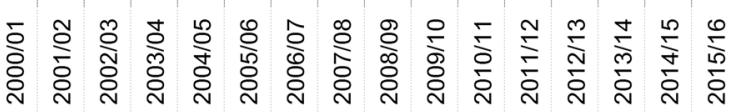

Fig. 2 Temporal spread of lynx observations over 16 monitoring years (May-April). The top panel refers to the spatial spread of the newly founded lynx population. $\mathrm{C} 1$ observations refers to the SCALP criteria of confirmed sighting in NI, ST, HE, TH, NW and BY. The study area was divided into $10 \times 10 \mathrm{~km}$ squares and number of squares occupied in each monitoring each calculated. The middle panel shows the number of genetic samples collected during the study period, showing the relationship between number of samples collected and number of confirmed unique indviduals. The bottom panel shows the type and duration of monitoring activity, with the numbers reporting the released individuals between 2000 and 2006

Mastermix (QIAGEN), with a negative control. Fragment analysis was performed on a 3730xl DNA Analyzer (Applied Biosystems). Consensus genotypes were derived using a custom $\mathrm{R}$ script based on the algorithms used in GIMLET 3.3 (Valière 2002) with a maximum of three mismatching loci accepted to assign a sample to the same individual. The customized script also takes gender, haplotype, sampling date and location into account. Samples between 2000 and 2015 were first run with 14 loci (Table S3) and later on the 19 loci set; in these cases we used results from both sets to create consensus genotypes of 19 loci. Therefore, estimation of sample quality and genotyping errors was carried out on both the 14 loci and 19 loci set.

Amplification success, allelic dropout (ADO), and false allele (FA) calculations were carried out based on the total replicates for each individual and the corresponding consensus genotype. Samples with $<25 \%$ amplification across all replicates were excluded.

\section{Population assignment}

Population ancestry of sampled individuals was analyzed using discriminant analysis of principal components (DAPC) implemented in the adegenet package (Jombart 2008) using R and STRUCTURE (Pritchard et al. 2000). We included 27 individuals from zoos, 10 sampled founders and 105 genotypes originating from the HLP. DAPC assumed seven clusters and retained the first six PCA axes, estimated by the optim.a.score and find.clusters function, which predicts the optimal number of principal components and clusters, respectively.

STRUCTURE was executed using the admixture model with correlated allele frequencies. $\mathrm{K}$ ranged from one to eight using a burn-in of 500,000 runs, following 500,000 MCMC runs. STRUCTURE runs were repeated 10 times for each K and CLUMPP 1.1.2 (Jakobsson and Rosenberg 2007) was used to match runs. The most likely number of clusters was investigated using the method described by Evanno et al. (2005) and implemented in STRUCTURE HARVESTER (Earl and vonHoldt 2012).

\section{Genetic diversity through time and generations}

Standard measures of genetic diversity including number of alleles (Na), observed (Ho) and unbiased expected heterozygosity (He) were calculated with GENALEX 6.5 (default settings) (Peakall and Smouse 2006) using the same groups defined for population assignment methods. In addition, each monitoring year (May 1st-April 30th) was considered as a distinct group in order to assess the development of the lynx population over time. Genetic diversity was also estimated for all sampled offspring born each monitoring year. Private alleles in all groups were evaluated using GENALEX 6.5 (Peakall and Smouse 2006). 


\section{Parentage analysis and analysis of pedigree}

Parentage estimation was conducted with COLONY 2.0 (Jones and Wang 2010; Wang 2004) allowing inbreeding with long run length, full-likelihood method with high precision, update of allele frequency and complexity prior. We used polygamy as the mating system to not exclude rare instances of polyandrous litters (Lucena-Perez et al. 2018). We included the prior error rates for each locus and allelic frequencies. Parent-offspring associations were tested in a stepwise approach for each monitoring year to account for known changes to the population, including confirmed births, deaths, and recapture events. As no total population estimates were given from year to year, probability of parent to be sampled based on initial population size and ratio of known individuals to the whole population was set to 0.2 for mothers and fathers.

For each monitoring year, we determined the set of candidate parents based on known adults ( $>3$ years). For six individuals, age was not determined from traditional monitoring and were included as candidate parents since the first year these individuals were sampled. Information on known sibling relationships (e.g. juveniles photographed together), parent-offspring relationships (e.g. mother photographed with offspring) and exclusion of parent relationships (e.g. mismatched haplotypes or death) was included a priori.

No threshold was set for assigning a parent-offspring relationship as the output was compared with monitoring data to refine the relationships defined by COLONY 2.0. Parent pairs were compared for compatible territories and known sitings of parental individuals. When no candidate parents were assigned to offspring in a target year, we sampled the parental genotypes inferred by COLONY 2.0. These unsampled individuals were considered in the following years. The derived pedigree was used to calculate inbreeding, kinship and estimate the number of generations with the $\mathrm{R}$ package pedigree and kinship 2 . The pedigree of reproducing individuals was visualized using the pedigree tool provided by Progeny Genetics (https://www.progenygen etics.com/online-pedigree/).

\section{Founder size}

Five out of 24 released animals died early or were removed from the population shortly after reintroduction (Anders, pers. communication), leaving 19 potential founders. For 10 of them (eight females and two males) genetic samples were available (Table S1). To estimate the number of founder individuals in the HLP, results from the parentage analysis, occurrence of private alleles and mitochondrial haplotypes were considered. We also ran ML-Relate to determine the degree of relatedness between sampled founders.

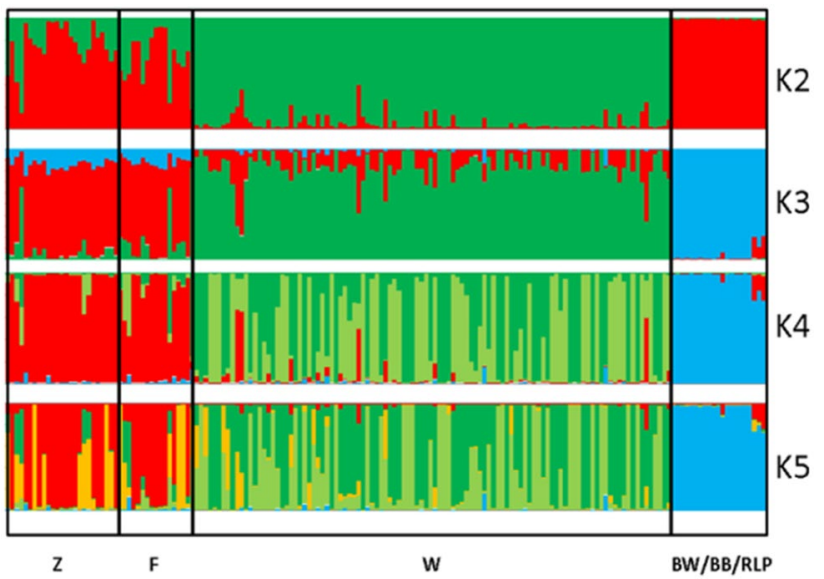

Fig. 3 STRUCTURE plots where each bar represents one individual. Most likely clusters $\mathrm{K}=2$ as indicated by STRUCTURE HARVESTER. Lynx from the Harz (W) were assigned to a distinct cluster separated from zoo $(\mathrm{Z})$, founder $(\mathrm{F})$, and individuals from BadenWurtenberg, Bohemian-Bavarian and Rhineland Pfalz reintroductions (BW/BB/RLP)

\section{Results}

\section{Sample collection and species determination}

Blood and tissue samples showed very high amplification and low $\operatorname{ADO}(0.08,0.02)$ and FA $(0.02,0.02)$. Of the noninvasive samples, hairs showed the highest rate of assigment to lynx (83\%), followed by scats $(73 \%)$ and saliva traces from prey remains (53\%). Hair samples showed the lowest ADO among the noninvasively collected samples (0.16), followed by scat samples (0.19). Lowest amplification (0.78) and highest $\mathrm{ADO}(0.29)$ were found in saliva traces. FA rates were lowest for saliva (0.03) with the highest rate $(0.10)$ found in scat samples (Table S2). Genotypes for all individuals can be found in Table S6.

\section{Haplotype frequencies}

The group of 10 sampled founders showed five haplotypes: L1, L2, L4, L6, L7 (Table S1). Three of those haplotypes were identified in 96 successfully analysed wild individuals ( $n=105$ ), with L1 found in 3, L4 in 84, and L6 in 9 individuals (Table S6).

\section{Population assignment}

Bayesian assignment implemented in STRUCTURE separated Harz individuals from sampled founders, captive lynx, and the BBA population. STRUCTURE HARVESTER indicated $\mathrm{K}=2$ as the likely number of clusters. Lynx individuals from zoos and sampled founders formed one cluster, and the individuals from the BBA population formed another 
distinct cluster. With a $\mathrm{K}=4$, the HLP formed two clusters (Fig. 3). These population subdivisions were largely confirmed by DAPC analysis (Fig. S1).

\section{Genetic diversity through time}

Between 2 and 14 alleles were found among the genotyped loci, a mean of 7.47 alleles per locus across all samples. When corrected for sample size, the HLP (3.32) showed lower average allele numbers than zoo (4.82) and founder (4.46) individuals. In contrast, observed and expected heterozygosity are comparable in zoo, founders, and the HLP, while considerably lower in BBA population (Table S4). Both the effective number of alleles and expected heterozygosity show a continuous decline over time (Fig. 4a, b). For observed heterozygosity, values initially rose and then show a similar decline. This pattern becomes stronger when considering generation sequence (only juveniles considered; Fig. 4a).

\section{Parentage and cohorts}

Analysis of relatedness using COLONY as well as additional data from field monitoring allowed to reconstruct a partial pedigree of the HLP, with the fifth generation of lynx confirmed in 2015/2016 (Fig. 5). COLONY estimated 16 sampled females and 9 sampled males as having reproduced in the HLP and the average assignment probability of parent pairs was $0.88 \pm 0.22$. Additional unsampled individuals were identified by COLONY as having contributed to the pedigree. We also considered known offspring and territories based on available field monitoring data to refine COLONY results. This resulted in a total of 43 individuals forming the final pedigree (Fig. 5) Twenty-two lynx were identified as influential breeding individuals, of which 5 have died or been taken out of the wild. Analysis of the partial pedigree revealed an average inbreeding rate of $0.01 \pm 0.03$ and mean kinship of $0.03 \pm 0.02$. Cases of two identified inbreeding events occurred in the first generations.

\section{Founder size}

Three reintroduced females (LL018, LL037, LL006) were confirmed to have offspring by camera traps during field monitoring and re-affirmed through COLONY. These confirmed females carried haplotypes L4 and L6. The seven remaining sampled founders were not assigned by COLONY to any sampled offspring. Two offspring of a putative fourth female (UF01 in the pedigree) were found to carry haplotype L1. At locus FCA026, eight alleles

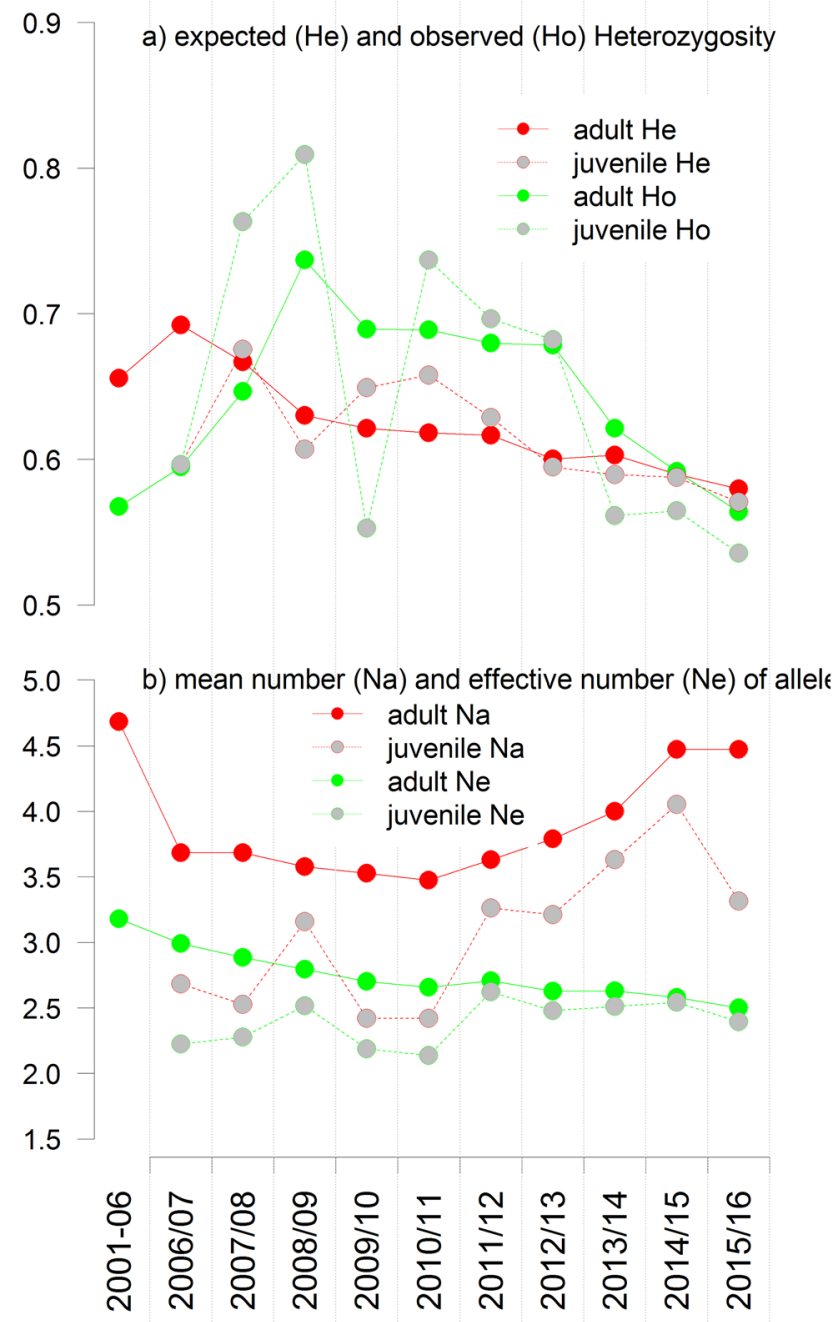

Fig. 4 Genetic diversity in the reintroduced Harz lynx population over time (2000-2016). a observed heterozygosity (Ho) and expected heterozygosity $(\mathrm{He})$ by year. $\mathbf{b}$ number of alleles $(\mathrm{Na})$ and number of effective alleles $(\mathrm{Ne})$ for each year. In both, dashed lines show values from juveniles confirmed or estimated to have been born within the monitoring year. Solid lines represent values from the entire population. Note that the first unit on the $\mathrm{x}$ axis represents the time span of reintroduction over multiple years

were detected which are not present in the three confirmed founder females. Founders were also analysed in MLRelate which found 2 sets of known siblings (Table S5). One set includes LL006, LL0036w, and LL0037w, which all orginate from Wildpark Neuhaus and share haplotype L4. LL0030m is a full sibling with LL0031w originating from Wildpark Edersee with haplotype L7. LL031w died in 2004, and the haplotype 7 has not been found in the HLP. LL006w and LL0037 are known to have reproduced and LL006w died in 2008. 


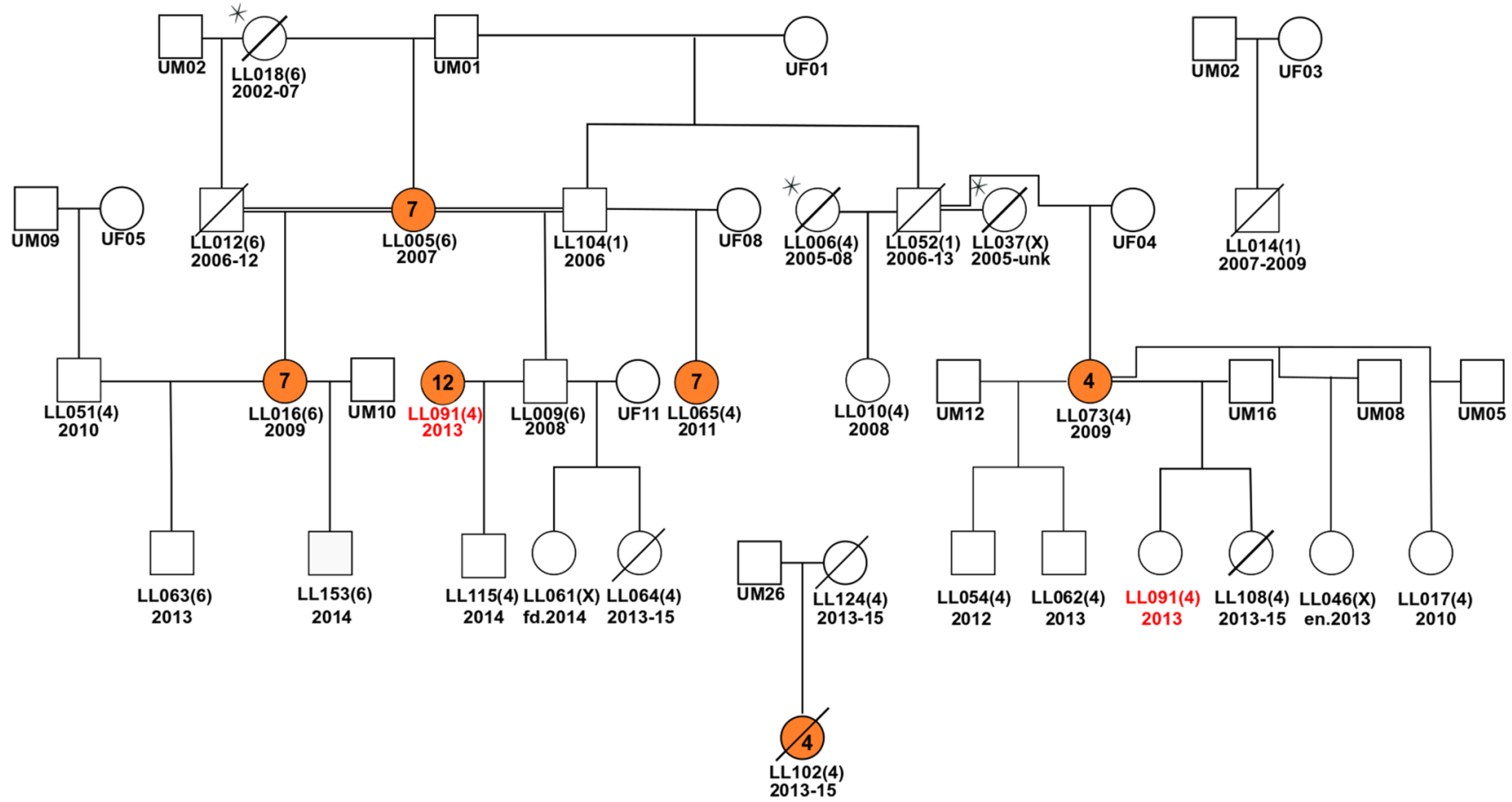

Fig. 5 Pedigree of all reproducing individuals in the Harz lynx population since the first reintroduction until 2016 based on COLONY results with aid from field monitoring and haplotype comparison. Individual identification number is followed by mitochondrial haplotype (in parentheses) and birth year below. When no birth year is

\section{Discussion}

The HLP has been monitored consecutively over the last 15 years using both traditional field methods and genetic analyses to track population size, demographic expansion and genetic diversity over time, with the ultimate goal to draw conclusions concerning the current status and likely future development of this reintroduced population.

The reintroduction of lynx from captivity in the HM initially received considerable concern. For instance, it was questioned if animals from captivity could survive in the wild and form a new population (Wotschikowsky et al. 2001). There was also some degree of uncertainty regarding the genetic origin of the released lynx, thus increasing the risk of inbred individuals (Laikre 1999), hybrids between subspecies (von Arx et al. 2009) or outbreeding depression (Huff et al. 2011) in the established population. In addition, there was apprehension about the successful dispersal across anthropogenic barriers to connect with other populations, which would maintain genetic diversity and ensure long-term viability (Kramer-Schadt et al. 2005). Our data show that despite the multiple concerns, lynx have spread over the past 15 years and form an expanding population with a decreasing level of genetic diversity. Given the number of failed reintroduction attempts across Europe, known the first detection year (fd.) is provided. Orange represents territorial breeding females identified through COLONY and confirmed with monitoring data and number of confirmed offspring is located within. Unknown male and female individuals identified by COLONY are marked with a UM/UF

the reconstruction and scientific analysis of the population growth of the reintroduced HLP is of considerable importance to guide future reintroduction attempts and work towards a long-term viable lynx metapopulation spreading across Europe.

\section{Population growth and expansion}

Our results support that since the release between 2000 and 2006, the HLP has experienced a substantial increase in population size and spatial spread across the HM and its surroundings, which has been found in other studies (Anders et al. 2012, 2016; Anders and Middelhoff 2016a, b). We have genetically identified 105 wildborn individuals from the HLP (Fig. 2), which have spread up to $280 \mathrm{~km}$ Euclidean distance from the area of reintroduction. As sampling was opportunistic and not evenly spread through space and time, this number likely only represents a fraction of all individuals between 2000 and 2016.

Several factors have contributed to the steady increase in size and spatial spread of the HLP. First, there are presumably low rates of illegal killing, with only a single detected case. Illegal killing is among the dominant factors preventing the spatial growth of lynx populations in Europe (Müller et al. 2014; López et al. 2014; Heurich et al. 2018; 
Červený et al. 2002). In the Bohemian forest, for instance, an estimated 62 lynx have been illegally hunted outside of the national park borders post-reintroduction (Müller et al. 2014). Second, there is a relatively consistent availability of roe deer (Capreolus capreolus) and other ungulate species in the HM region likely providing suitable conditions for the establishment and growth of a stable lynx population. Lynx are more sensitive to changes in habitats and prey abundance than other large carnivores, making both forest cover and availability of prey important factors in determining the likelihood of survival (Bagrade et al. 2016; Schmidt et al. 2011). This rapid demographic and spatial expansion confirms that reintroduction of captive born lynx is possible, which has important consequences for future reintroduction planning. As the current availability of wild caught lynx is highly restricted in Europe and poses a significant impediment for current reintroduction attempts (Krebühl, pers. comm.), we show here a potential alternative for the costly and laborious capture of animals in the wild.

\section{Declining genetic diversity over time}

While standard measures of genetic diversity for the HLP are higher than for other reintroduced populations (e.g., He of 0.50 compared to 0.43 in BBA), they do not match levels seen in autochthonous populations (Supplementary Material 1). The HLP experienced a demographic bottleneck postreintroduction, as a low number of released individuals reproduced (Fig. 5). This demographic bottleneck has been well documented in other lynx reintroductions across Central Europe (Schmidt et al. 2011; Sindičić et al. 2013b; Abascal et al. 2016). STRUCTURE and DAPC results show that the HLP now forms a cluster, which is separated from the founders and sampled zoo individuals (Fig. 3 and Fig. S1). In addition to this central HLP cluster, some individuals group in the vicinity of other released individuals, which have not been identified as founders in this study. As we are unfortunately missing genetic data on nine potential founders, it appears likely that we are not able to generate a complete picture of population establishment in this study. The genetic structure during the initial population founding phase, including those genetically distant individuals, might thus be explained by the genetic contribution of unsampled founder individuals. In 2008/2009 we saw observed heterozygosity (0.74), expected heterozygosity (0.61), and number of effective alleles (3.6) considerably elevated in the F1 generation (Fig. 4). Likely, this is a result of distant captive lineages mating in the wild. We currently see a decline across these measures of genetic diversity; after 7 years observed heterozygosity (0.56), expected heterozygosity ( 0.57$)$, and number of effective alleles (2.92) all showed some degree of decline (Fig. 4). Interestingly, the overall number of alleles rose from 3.6 to 2009 to 4.5 in 2016 . However, this can be attributed to a higher number of samples being collected due to more intensive genetic monitoring (Fig. 2). This downward trend suggests that genetic diversity will likely continue to decline in the future, likely resulting in similarly low values as currently observed in the other European lynx reintroduction areas, if no gene flow through some degree of population exchange happens. Notably, there is evidence of long distance dispersal of single males from the HM to a distance of up to $280 \mathrm{~km}$, which documents the potential of lynx to disperse across fragmented anthropogenic landscapes in Central Europe. Such long distance dispersal has been documented previously in Central Europe (Zimmermann et al. 2005; Schmidt 1998). This evidence raises hope for the long-term conservation goal of connecting isolated lynx populations in Central Europe, ultimately leading to the formation of a viable metapopulation (Breitenmoser-Würsten et al. 2007). However, the next years will likely show if the population is capable of spreading further into more fragmented areas while sustaining territorial and reproducing females. Therefore, there is a heightened importance for continued genetic population monitoring to screen genetic diversity, inbreeding and gene flow.

Founder size and pedigree Pedigree reconstruction revealed a low founder size with reproductive success of the population contingent upon a small number of territorial, prolific breeders. Kramer-Schadt et al. (2005) argued that a minimum of ten females is necessary to establish a sustainable population. Our haplotype and COLONY results indicate that the founder size of the HLP consisted of a minimum of seven individuals (four females and three males). We cannot rule out the possibility that some of the ten undocumented escapes and illegal releases of lynx in the study area contributed to reproduction. While this is likely the highest number of founder individuals reached in a reintroduction (von Arx et al. 2009), seven founders are not sufficient to form a genetically sustainable population without considerable levels of inbreeding. This confirms that the release of a relatively high number of animals is vital to reach a moderate number of genetically significant founders. Our pedigree confirms two instances of inbreeding, which is likely an underestimate given the relatedness analysis finding one pair of full siblings within the founders of the HLP. This inbreeding rate is therefore a highly conservative estimate.

Finally, the pedigree shows that only 25 of the 115 genetically identified individuals, including founders, have certainly reproduced. These reproducing individuals tend to be well established territorial individuals from the $1 \mathrm{st}$ and 2nd generations (Fig. 5). It must be taken into consideration that several reproducing individuals have not been genetically identified, as shown by unknown individuals in the pedigree, so the number of well-established territorial individuals is likely underestimated. However, a 
comparably low number of reproducing individuals has also been noticed in other lynx populations (Schmidt et al. 2016; Krojerová-Prokešová et al. 2018; Holmala et al. 2018).

\section{Conclusions}

Long term post-release monitoring over the past two decades has enabled a detailed reconstruction of the demographic history of the Eurasian lynx in the HM. Despite a low number of founders, the captive origin of released individuals, and highly divergent reproductive success within the population, we conclude that the population is currently growing despite the continuing loss of genetic diversity occuring in each subsequent generation. If the growth continues further, we believe that the HLP might become one of the cornerstones of the envisioned interconnected Central European metapopulation, which will ensure long-term establishment and survival of the lynx within the human-dominated Central European landscape. To ensure this natural exchange, it is vital to keep illegal killing low and facilitate the permeability of potential migration corridors (Kramer-Schadt et al. 2005). Additionally, the translocation of individuals between different reintroductions or from authochtonous populations to stabilize declining genetic diversity and mitigate genetic drift appears a necessary measure until a sufficient level of natural geneflow occurrs between the reintroduction areas.

We strongly urge for the continuation of an efficient genetic and demographic monitoring of the current HLP as well as adjacent reintroduced lynx populations. Detailed knowledge on the development of population status, inbreeding and genetic diversity is crucial for the implementation of optimized conservation strategies. This is particularly true for a species divided into small, isolated subpopulations such as the lynx in Central Europe. Despite the genetic depletion, the population growth of the species within a densely populated country such as Germany proves that, given an appropriate genetic long-term management, lynx may successfully establish and persist in anthropogenic landscapes.

Acknowledgements Open Access funding provided by Projekt DEAL. Funding and support for this project comes from Harz National Park and other conservation initiatives. We are deeply grateful to all students who aided in field and lab work. Special thanks go to Jenny Wertheimer and Verena Harms. SM is funded by the DAAD (German Academic Exchange Service), CREOi (Conservation, Research and Education Opportunities International) and the University of California Santa Cruz. All DNA sequencing and fragment length analyses in this study were performed in the laboratory center of the Senckenberg BiK-F funded by the LOEWE initiative (Landes-Offensive zur Entwicklung Wissenschaftlich-ökonomischer Exzellenz) of the Federal State of Hessen.

\section{Compliance with ethical standards}

Conflict of interest The authors are not aware of any conflicts of interest.

Open Access This article is licensed under a Creative Commons Attribution 4.0 International License, which permits use, sharing, adaptation, distribution and reproduction in any medium or format, as long as you give appropriate credit to the original author(s) and the source, provide a link to the Creative Commons licence, and indicate if changes were made. The images or other third party material in this article are included in the article's Creative Commons licence, unless indicated otherwise in a credit line to the material. If material is not included in the article's Creative Commons licence and your intended use is not permitted by statutory regulation or exceeds the permitted use, you will need to obtain permission directly from the copyright holder. To view a copy of this licence, visit http://creativecommons.org/licenses/by/4.0/.

\section{References}

Abascal F, Corvelo A, Cruz F, Villanueva-Cañas JL, Vlasova A, Marcet-Houben $\mathrm{M}$ et al (2016) Extreme genomic erosion after recurrent demographic bottlenecks in the highly endangered Iberian lynx. Genome Biol 17(1):251. https://doi.org/10.1186/s1305 9-016-1090-1

Anders O (2013) Luchsprojekt Harz. Bericht Monitoringjahre 2011/12 und 2012/13. Nationalpark HarzWernigerode, Wernigerode

Anders O, Middelhoff TL (2016a) Der Einsatzes von Fotofallen beim Monitoring des Luchsbestandes (Lynx lynx) im Harz - Abundanz und Dichte im Herbst und Winter 2015/16. Beiträge zur Jagd- und Wildtierforschung 41:319-331

Anders O, Middelhoff TL (2016b) Abundanz und Dichte des Luchses (Lynx lynx) in westlichen Harz. Die Ergebnisse eines systematischen Fotofallenmonitorings im Herbst und Winter 2014/15. Säugetierkundliche Informationen 51:213-224

Anders O, Sacher P (2005) Das Luchsprojekt Harz - ein Zwischenbericht. Naturschutz im Land Sachsen-Anhalt 42(2):3-12

Anders O, Kaphegyi TAM, Kubik F (2012) Untersuchungen zum Dispersionsverhalten eines männlichen Luchses (Lynx lynx) im Dreiländereck zwischen Thüringen, Niedersachsen und Hessen. In Säugetierkundliche Informationen 45(8):455-462

Anders O, Middelhoff TL, Dobrescu B, Kajanus M (2016) Wie kommt der Luchs (Lynx lynx) aus dem Harz heraus? Untersuchungen zur Durchlässigkeit von Bundesstraßen- und Autobahnunterführungen. Säugetierkundliche Informationen 51(10):225-236

Bagrade G, Ruṇgis DE, Ornicāns A, Šuba J, Žunna A, Howlett SJ et al (2016) Status assessment of Eurasian lynx in Latvia linking genetics and demography-a growing population or a sourcesink process? Mamm Res 61(4):337-352. https://doi.org/10.1007/ s13364-016-0279-8

Boitani L, Alvarez F, Anders O, Andren H, Avanzinelli E, Balys V et al (2015) Key actions for Large Carnivore populations in Europe. With assistance of Report to DG Environment, European Commission, Bruxelles. Contract no. 07.0307/2013/654446/SER/B3. Institute of Applied Ecology, Rome

Breitenmoser-Würsten C, Obexer-Ruff G (2003) Population and conservation genetics of two re-introduced lynx (Lynx lynx) populations in Switzerland-a molecular evaluation 30 years after translocation. Environ Encount 58:51-55

Breitenmoser-Würsten C, Zimmermann F, Molinari-Jobin A, Molinari P, Capt S, Vandel J et al (2007) Spatial and Social stability of a Eurasian lynx Lynx lynx population: an assessment of 10 
years of observation in the Jura Mountains. Wildl Biol 13(4):365380. https://doi.org/10.2981/0909-6396(2007)13[365:SASSO A]2.0.CO;2

Bull JK, Heurich M, Saveljev AP, Schmidt K, Fickel J, Förster DW (2016) The effect of reintroductions on the genetic variability in Eurasian lynx populations: the cases of Bohemian-Bavarian and Vosges-Palatinian populations. Conserv Genet 17(5):1229-1234. https://doi.org/10.1007/s10592-016-0839-0

Carmichael LE, Clark W, Strobeck C (2000) Development and characterization of microsatellite loci from lynx (Lynx canadensis), and their use in other felids. Mol Ecol 9(12):2197-2199. https://doi. org/10.1046/j.1365-294X.2000.105323.x

Červený J, Koubek P, Bufka L (2002) Eurasian Lynx (Lynx Lynx) and its chance for survival in Central Europe: the case of the Czech Republic. Acta Zool Litu 12(4):428-432. https://doi. org/10.1080/13921657.2002.10512534

Chapron G, Kaczensky P, Linnell JDC, von Arx M, Huber D, Andrén $\mathrm{H}$ et al (2014) Recovery of large carnivores in Europe's modern human-dominated landscapes. Science (New York, N.Y.) 346(6216):1517-1519. https://doi.org/10.1126/science.1257553

Davoli F, Schmidt K, Kowalczyk R, Randi E (2013) Hair snaring and molecular genetic identification for reconstructing the spatial structure of Eurasian lynx populations. Mammalian Biology Zeitschrift für Säugetierkunde 78(2):118-126. DOI:https://doi. org/10.1016/j.mambio.2012.06.003

de Barba M, Waits LP, Garton EO, Genovesi P, Randi E, Mustoni A, Groff C (2010) The power of genetic monitoring for studying demography, ecology and genetics of a reintroduced brown bear population. Mol Ecol 19:3938-3951

Earl DA, vonHoldt BM (2012) STRUCTURE HARVESTER: a website and program for visualizing STRUCTURE output and implementing the Evanno method. Conserv Genet Resour 4(2):359-361. https://doi.org/10.1007/s12686-011-9548-7

Evanno G, Regnaut S, Goudet J (2005) Detecting the number of clusters of individuals using the software STRUCTURE: a simulation study. Mol Ecol 14(8):2611-2620. https://doi.org/10.1111/j.1365294X.2005.02553.x

Gugolz D, Bernasconi MV, Breitenmoser-Würsten C, Wandeler P (2008) Historical DNA reveals the phylogenetic position of the extinct Alpine lynx. J Zool 275(2):201-208. https://doi.org/10.1 111/j.1469-7998.2008.00428.x

Harms V, Nowak C, Carl S, Muñoz-Fuentes V (2015) Experimental evaluation of genetic predator identification from saliva traces on wildlife kills. J Mammal 96:138-143

Hellborg L, Walker CW, Rueness EK, Stacy JE, Kojola I, Valdmann $\mathrm{H}$ et al (2002) Differentiation and levels of genetic variation in northern European lynx (Lynx lynx) populations revealed by microsatellites and mitochondrial DNA analysis. Conserv Genet 3(2):97-111. https://doi.org/10.1023/A:1015217723287

Heurich M, Schultze-Naumburg J, Piacenza N, Magg N, Červený J, Engleder $\mathrm{T}$ et al (2018) Illegal hunting as a major driver of the source-sink dynamics of a reintroduced lynx population in Central Europe. Biol Conserv 224:355-365. https://doi.org/10.1016/j. biocon.2018.05.011

Hollerbach L, Heurich M, Reiners TE, Nowak C (2018) Detection dogs allow for systematic non-invasive collection of DNA samples from Eurasian lynx. Mamm Biol 90:42-46

Holmala K, Herrero A, Kopatz A, Schregel J, Eiken HG, Hagen SB (2018) Genetic evidence of female kin clusters in a continuous population of a solitary carnivore, the Eurasian lynx. Ecol Evol 8(22):10964-10975. https://doi.org/10.1002/ece3.4562

Hucht-Ciorga I (2012) Luchsmonitoring (Lynx lynx) in NordrheinWestfalen - Hinweise aus den Jahren 1985-2011. Säugetierkdl. Inf. 45:463-481

Huff DD, Miller LM, Chizinski CJ, Vondracek B (2011) Mixedsource reintroductions lead to outbreeding depression in second-generation descendents of a native North American fish. Mol Ecol 20(20):4246-4258. https://doi.org/10.1111/j.1365294X.2011.05271.x

Jakobsson M, Rosenberg NA (2007) CLUMPP: a cluster matching and permutation program for dealing with label switching and multimodality in analysis of population structure. Bioinformatics (Oxford England) 23(14):1801-1806. https://doi.org/10.1093/ bioinformatics/btm 233

Jombart T (2008) adegenet: a R package for the multivariate analysis of genetic markers. Bioinformatics 24(11):1403-1405. DOI:https ://doi.org/10.1093/bioinformatics/btn129

Jones OR, Wang J (2010) COLONY: a program for parentage and sibship inference from multilocus genotype data. Mol Ecol Resour 10(3):551-555. https://doi.org/10.1111/j.1755-0998.2009.02787.x

Kaczensky P, Kluth G, Knauer F, Rauer G, Reinhardt I, Wotschikowsky U (2009) Monitoring of Large Carnivores in Germany. Hg. v. Federal Agency for Nature Conservation (Bundesamt für Naturschutz) (BfN-Skripten, 251)

Kramer-Schadt S, Revilla E, Wiegand T, Breitenmoser U (2004) Fragmented landscapes, road mortality and patch connectivity: modelling influences on the dispersal of Eurasian lynx. J Appl Ecol 41(4):711-723. https://doi.org/10.111 1/j.0021-8901.2004.00933.x

Kramer-Schadt S, Revilla E, Wiegand T (2005) Lynx reintroductions in fragmented landscapes of Germany: projects with a future or misunderstood wildlife conservation? Biol Conserv 125(2):169-182. https://doi.org/10.1016/j.biocon.2005.02.015

Krojerová-Prokešová J, Turbaková B, Jelenčič M, Bojda M, Kutal M, Skrbinšek T et al (2018) Genetic constraints of population expansion of the Carpathian lynx at the western edge of its native distribution range in Central Europe. Heredity. https:// doi.org/10.1038/s41437-018-0167-x

La Haye MJJ, Reiners TE, Raedts R, Verbist V, Koelewijn HP (2017) Genetic monitoring to evaluate reintroduction attempts of a highly endangered rodent. Conserv Genet 18(4):877-892

Laikre L (1999) Conservation genetics of Nordic carnivores: lessons from zoos. Hereditas 130(3):203-216

Linnell JDC, Breitenmoser U, Breitenmoser-Wrsten C, Odden J, von Arx M (2009) Recovery of Eurasian Lynx in Europe: what part has reintroduction played? In: Hayward M, Somers MJ (eds) Reintroduction of top-order predators. Wiley-Blackwell, Chichester, pp 72-91

Lucena-Perez M, Soriano L, López-Bao JV, Marmesat E, Fernández L, Palomares F et al (2018) Reproductive biology and genealogy in the endangered Iberian lynx: implications for conservation. Mamm Biol 89:7-13

López G, López-Parra M, Garrote G, Fernández L, del Rey-Wamba T, Arenas-Rojas R et al (2014) Evaluating mortality rates and causalities in a critically endangered felid across its whole distribution range. Eur J Wildl Res 60(2):359-366. DOI:https:// doi.org/10.1007/s10344-013-0794-8

Menotti-Raymond M, David VA, Lyons LA, Schäffer AA, Tomlin JF, Hutton MK, O'Brien SJ (1999) A genetic linkage map of microsatellites in the domestic cat (Felis catus). Genomics 57(1):9-23. https://doi.org/10.1006/geno.1999.5743

Menotti-Raymond MA, David VA, Wachter LL, Butler JM, O'Brien SJ (2005) An STR forensic typing system for genetic individualization of domestic cat (Felis catus) samples. J Forensic Sci 50(5):1061-1070

Molinari-Jobin A (2003) The pan-Alpine conservation strategy for the lynx (Nature and environment, no. 130). Council of Europe Publishing, Strasbourg

Molinari-Jobin A, Marboutin E, Wölfl S, Wölfl M, Molinari P, Fasel $M$ et al (2010) Recovery of the Alpine lynx Lynx lynx metapopulation. Oryx 44(02):267. DOI:https://doi.org/10.1017/S0030 605309991013 
Molinari-Jobin A, Kéry M, Marboutin E, Molinari P, Koren I, Fuxjäger $C$ et al (2012) Monitoring in the presence of species misidentification: the case of the Eurasian lynx in the Alps. Anim Conserv 15(3):266-273. DOI:https://doi.org/10.111 1/j.1469-1795.2011.00511.x

Müller J, Wölfl M, Wölfl S, Müller DWH, Hothorn T, Heurich M (2014) Protected areas shape the spatial distribution of a European lynx population more than 20 years after reintroduction. Biol Conserv 177:210-217. https://doi.org/10.1016/j.bioco n.2014.07.007

Peakall ROD, Smouse PE (2006) genalex 6: genetic analysis in Excel. Population genetic software for teaching and research. Mol Ecol Notes 6(1):288-295. DOI:https://doi.org/10.111 $1 / \mathrm{j} .1471-8286.2005 .01155 . \mathrm{x}$

Pritchard JK, Stephens M, Donnelly P (2000) Inference of population structure using multilocus genotype data. Genetics 155(2):945-959

Ratkiewicz M, Matosiuk M, Kowalczyk R, Konopiński MK, Okarma $\mathrm{H}$, Ozolins J et al (2012) High levels of population differentiation in Eurasian lynx at the edge of the species' western range in Europe revealed by mitochondrial DNA analyses. Anim Conserv 15(6):603-612. https://doi.org/10.1111/j.1469-1795.2012.00556.x

Ratkiewicz M, Matosiuk M, Saveljev AP, Sidorovich V, Ozolins J, Männil P et al (2014) Long-range gene flow and the effects of climatic and ecological factors on genetic structuring in a large, solitary carnivore: the Eurasian lynx. PloS ONE 9(12):e115160. https://doi.org/10.1371/journal.pone.0115160

Reinhardt I, Kaczensky P, Knauer F, Rauer G, Kluth G, Wolfl S et al (2015) Monitoring von Wolf, Luchs und Bär in Deutschland. Hg. v. Bundesamt für Naturschutz (BfN-Skripten, 413)

Ripple WJ, Estes JA, Beschta RL, Wilmers CC, Ritchie EG, Hebblewhite $M$ et al (2014) Status and ecological effects of the world's largest carnivores. Science (New York, N.Y.) 343(6167):1241484. https://doi.org/10.1126/science.1241484

Rodríguez-Varela R, García N, Nores C, Álvarez-Lao D, Barnett R, Arsuaga JL, Valdiosera C (2016) Ancient DNA reveals past existence of Eurasian lynx in Spain. J Zool 298(2):94-102. https://doi. org/10.1111/jzo.12289

Rueness EK, Naidenko S, Trosvik P, Stenseth NC (2014) Large-scale genetic structuring of a widely distributed carnivore-the Eurasian lynx (Lynx lynx). PloS ONE 9(4):e93675. https://doi.org/10.1371/ journal.pone.0093675

Schmidt K (1998) Maternal behaviour and juvenile dispersal in the Eurasian lynx. Acta Theriol 43:391-408. DOI:https://doi. org/10.4098/AT.arch.98-50

Schmidt K, Kowalczyk R (2006) Using scent-marking stations to collect hair samples to monitor Eurasian Lynx populations. Wildl Soc Bull 34(2):462-466. https://doi.org/10.2193/00917648(2006)34[462:USSTCH]2.0.CO;2

Schmidt K, Kowalczyk R, Ozolins J, Männil P, Fickel J (2009) Genetic structure of the Eurasian lynx population in north-eastern Poland and the Baltic states. Conserv Genet 10(2):497-501. https://doi. org/10.1007/s10592-008-9795-7
Schmitz OJ, Hawlena D, Trussell GC (2010) Predator control of ecosystem nutrient dynamics. Ecol Lett 13(10):1199-1209. https:// doi.org/10.1111/j.1461-0248.2010.01511.x

Schmidt K, Ratkiewicz M, Konopinski MK (2011) The importance of genetic variability and population differentiation in the Eurasian lynx Lynx lynx for conservation, in the context of habitat and climate change. Mammal Rev 41(2):112-124. https://doi.org/10. 1111/j.1365-2907.2010.00180.x

Schmidt K, Davoli F, Kowalczyk R, Randi E (2016) Does kinship affect spatial organization in a small and isolated population of a solitary felid: the Eurasian lynx? Integr Zool 11(5):334-349. https://doi. org/10.1111/1749-4877.12182

Sindičić M, Gomerčić T, Polanc P, Krofel M, Slijepčević V, Gembarovski N et al (2013a) Kinship analysis of Dinaric lynx (Lynx lynx) population. Šumarski list 137(1-2):43-49

Sindičić M, Polanc P, Gomerčić T, Jelenčič M, Huber Đ, Trontelj P, Skrbinšek T (2013b) Genetic data confirm critical status of the reintroduced Dinaric population of Eurasian lynx. Conserv Genet 14(5):1009-1018. https://doi.org/10.1007/s10592-013-0491-x

Trouwborst A (2010) Managing the carnivore comeback: international and EU species protection law and the return of lynx, wolf and bear to Western Europe. J Environ Law 22(3):347-372. https:// doi.org/10.1093/jel/eqq013

Valière N (2002) gimlet: a computer program for analysing genetic individual identification data. Mol Ecol Notes 2(3):377-379. https ://doi.org/10.1046/j.1471-8286.2002.00228.x-i2

von Arx M, Breitenmoser-Würsten C, Breitenmoser U (2009) Lessons from the reintroduction of the Eurasian lynx in Central and West Europe (Lecciones aprendidas a partir de la reintroducción del lince boreal en Europa Central y Occidental). In Iberian Lynx ex situ conservation: an interdisciplinary approach, pp. 403-409

Wang J (2004) Sibship reconstruction from genetic data with typing errors. Genetics 166(4):1963-1979. https://doi.org/10.1534/genet ics.166.4.1963

Williamson JE, Huebinger RM, Sommer JA, Louis EE, Barber RC (2002) Development and cross-species amplification of 18 microsatellite markers in the Sumatran tiger (Panthera tigris sumatrae). Mol Ecol Notes 2(2):110-112. DOI:https://doi.org/10.104 6/j.1471-8286.2002.00163.x

Wotschikowsky U, Kaczensky P, Knauer F (2001) Wiederansiedlung des Luchses im Harz. Eine kritische Stellungnahme aus wildbiologischer Sicht. Naturschutz Landschaftsplanung 33(8):259-260

Zimmermann F, Breitenmoser-Würsten C, Breitenmoser U (2005) Natal dispersal of Eurasian lynx (Lynx lynx) in Switzerland. J Zool 267(04):381. https://doi.org/10.1017/S0952836905007545

Publisher's Note Springer Nature remains neutral with regard to jurisdictional claims in published maps and institutional affiliations. 